\title{
Infertility Treatments, Mental Wellbeing \& Yoga
}

\author{
Anjali Raj* \\ YAI Certified Pregnancy Yoga Instructor, UK
}

Submission: April 06, 2018; Published: May 24, 2018

*Corresponding author: Anjali Raj, PhD Student (WMS), L.C.C.E., C.L.E., DipHB (KG), YAI Certified Pregnancy Yoga Instructor, UK, Email: A.Raj@warwick.ac.uk

\section{Introduction}

Infertility i.e. the inability to have children affects men and women across the globe. A couple is considered infertile if the woman has not conceived post having unprotected sex for 12 months. As per Mascarenhas et al. [1], 48.5 million couples across the world suffer from infertility and prevalence of these cases was highest in South Asia, Sub-Saharan Africa, North Africa/ Middle East, and Central/Eastern Europe and Central Asia. One of the most common problems faced by women undergoing infertility treatments are anxiety, stress and depression. Campagne [2] suggests that stress reduction is an cost-effective and non-invasive method to improve fertility in women. Lintsen et al. [3] and Domar et al. [4] recommend research in the field of complimentary therapy and introduction of interventions to reduce stress levels in women undergoing fertility treatments to combat the manifestations of stress. There have been studies been done of how yoga can be useful in this patient population. Research trials of infertility and Yoga have been done only in the last 5 years. Given the recent interest of researchers and clinical practitioners into this area, a review of current literature and a discussion seems timely.

\section{Double edged effect of infertility on mental well being}

Anxiety and stress are common amongst women undergoing fertility treatments due to their state of infertility and more importantly, the uncertainty of results $[5,6]$. Infertility treatments are a cause for chronic stress as the couple has been going through successive cycles of hope and dejection [4].

Lintsen et al. [3] discusses three multidimensional sources of stress during an infertility treatment. Firstly, the threat that infertility can be permanent. Secondly, the prospect of the fertility treatment itself and lastly, the procedural stress of the actual treatment itself. Infertility evaluation and treatment can be one of the lowest points in a woman's life [7]. In a study by Veerhaak et al. [8], it was concluded that $20 \%$ of women showed some subclinical form of anxiety and/or depression post an unsuccessful treatment. A study by Chen et al. [9] reported that over $40 \%$ of women visiting an infertility clinic had some form of clinical depressive/anxiety disorder. Stress levels faced by an infertile woman have been shown to be equivalent to individuals suffering from cancer, cardiac diseases and chronic hypertension [4].

Physiologically, interference in gonadotrophin secretion, catecholamine effects on the uterus and fallopian tube and disturbances in the implantation process are few of the effects stress reactions can have on reproduction [10]. The Hypothalamic-Pituitary-Adrenal (HPA) Axis and the stress hormones in the body interact with hormones like Gonadotropinreleasing hormone $(\mathrm{GnRH})$, prolactin, Follicle-stimulating hormone (FSH) and Luteinizing hormone (LH) which have a direct influence on fertility and with melatonin, cortisol and endogenous opioids which can interfere with fertility $[2,11]$.

Raoul Duval et al. [12] reported that the psychological issues faced by couples conceiving with help of infertility treatments can carry on during pregnancy and has the probability to affect early parenting. These women suffer from greater anxiety during pregnancy $[13,14]$ and reports antenatal complaints more often [15] which has a trickledown effect [16] into higher rates of hospital admissions for minor problems like a back pain [17]. A study of 45 couples during their infertility treatment, pregnancy and birth identified that the psychological burden was higher than physical burden and the pregnancy was perceived to be more stressful than the controls with spontaneous conception [18]. In a study by Monti et al. [19] Edinburgh Postnatal Depression Scores (EPDS) collected at 3032 weeks gestation, 1 week after birth and 3 months after birth, reported higher scores in infertility treatment led pregnancies as compared to spontaneous conception pregnancies. The study also reported significantly higher number of depressed subjects in the treatment led pregnancy group as compared to controls. Maternal self-esteem, which is usually affected by stress/ anxiety, has been studied to be directly correlated to the infant's gestational age [20].

\section{Does stress affect treatment outcomes?}

There is contraindicating evidence to effect of stress levels on infertility treatment outcomes. Lower stress levels indicate 
better fertility in men and women. A study on impact of stress on fecundity indicated that high stress levels can significantly affect chances of conception [21]. While few studies indicate that stress can have a negative impact on fertility treatment outcome [11,22-24], some studies including a meta-analysis of 14 studies [25], indicate that there is no dependant relationship between the outcome of treatments and stress levels in women $[2,26]$ and also that, anxiety and depression levels before and during treatments have no significant influence on the cancellation and pregnancy rates of participants [3]. However, distress is one of the most common reasons given by fertility treatment patients who wish to voluntarily terminate the treatment process $[27,28]$. Psychological distress can interfere directly or indirectly on the success of treatment at least in terms of continuation of treatment making it a critical component in successful pregnancy rates [5]. Monitoring and decreasing stress levels at baseline is critical in successful IVF treatments [11].

\section{References}

1. Mascarenhas MN, Flaxman SR, Boerma T, Vanderpoel S, Stevens GA (2012) National, regional, and global trends in infertility prevalence since 1990: a systematic analysis of 277 health surveys. PLoS Med 9(12): e1001356.

2. Campagne DM (2006) Should fertilization treatment start with reducing stress? Human Reproduction 21(7): 1651-1658.

3. Lintsen A, Verhaak C, Eijkemans M, Smeenk J, Braat D (2009) Anxiety and depression have no influence on the cancellation and pregnancy rates of a first IVF or ICSI treatment. Human Reproduction 24(5) 1092-1098.

4. Domar AD, Zuttermeister PC, Friedman R (1993) The psychological impact of infertility: a comparison with patients with other medical conditions. J Psychosom Obstet Gynaecol 14: 45-45.

5. Cousineau TM, Domar AD (2007) Psychological impact of infertility. Best Pract Res Clin Obstet Gynaecol 21(2): 293-308.

6. Volgsten H, Skoog Svanberg A, Ekselius L, Lundkvist O, Sundström Poromaa I (2008) Prevalence of psychiatric disorders in infertile women and men undergoing in vitro fertilization treatment. Hum Reprod 23(9): 2056-2063.

7. Freeman EW, Boxer AS, Rickels K, Tureck R, Mastroianni L (1985) Psychological evaluation and support in a program of in vitro fertilization and embryo transfer. Fertil Steril 43(1): 48-53.

8. Verhaak CM, Lintsen BM, Kraaimaat FW, Kremer JA, Braat DD (2006) 0-6: Who is at risk of developing emotional problems after in vitro fertilization (IVF): Pre treatment identification of risk groups. Fertility and Sterility 86(3 Suppl): S3.

9. Chen TH, Chang SP, Tsai CF, Juang KD (2004) Prevalence of depressive and anxiety disorders in an assisted reproductive technique clinic. Hum Reprod 19(10): 2313-2318.

10. Reading AE, Chang LC, Kerin JF (1989) Attitudes and anxiety levels in women conceiving through in vitro fertilization and gamete intrafallopian transfer. Fertil Steril 52(1): 95-99.

11. Klonoff Cohen H, Chu E, Natarajan L, Sieber W (2001) A prospective study of stress among women undergoing in vitro fertilization or gamete intrafallopian transfer. Fertil Steril 76(4): 675-687.

12. Raoul Duval A, Bertrand Servais M, Letur Könirsch H, Frydman R (1994) Infertility: Psychological follow-up of children born after invitro fertilization. Human Reproduction 9(6): 1097-1101.
13. Hjelmstedt A, Widström A, Wramsby HM, Collins A (2003) Patterns of emotional responses to pregnancy, experience of pregnancy and attitudes to parenthood among IVF couples: a longitudinal study. J Psychosom Obstet Gynaecol 24(3): 153-162.

14. Slade P, Emery J, Lieberman BA (1997) A prospective, longitudinal study of emotions and relationships in in-vitro fertilization treatment. Hum Reprod 12(1): 183-190.

15. Younger M, Hollins Martin C, Choucri L (2015) Individualised care for women with assisted conception pregnancies and midwifery practice implications: an analysis of the existing research and current practice. Midwifery 31(2): 265-270.

16. Hammarberg K, Fisher JR, Rowe HJ (2008) Women's experiences of childbirth and post-natal healthcare after assisted conception. Hum Reprod 23(7): 1567-1573.

17. Bryan A (2000) The psychosocial effects of infertility and the implications for midwifery practice. MIDIRS Midwifery Dig 10(1): 8-12.

18. Balen FV, Naaktgeboren N, Trimbos Kemper TC (1996) In-vitro fertilization: the experience of treatment, pregnancy and delivery. Human Reproduction 11(1): 95-98.

19. Monti F, Agostini F, Fagandini P, La Sala GB, Blickstein I (2009) Depressive symptoms during late pregnancy and early parenthood following assisted reproductive technology. Fertil Steril 91(3): 851857.

20. Edwards CH, Cole OJ, Oyemade UJ, Knight EM, Johnson AA, et al. (1994) Maternal stress and pregnancy outcomes in a prenatal clinic population. J Nutr 124 (6 Suppl): 1006S-1021S.

21. Louis GM, Lum KJ, Sundaram R, Chen Z, Kim S, et al. (2011) Stress reduces conception probabilities across the fertile window: evidence in support of relaxation. Fertil Steril 95(7): 2184-2189.

22. Ebbesen SM, Zachariae R, Mehlsen MY, Thomsen D, Højgaard A, et al. (2009) Stressful life events are associated with a poor in-vitro fertilization (IVF) outcome: a prospective study. Hum Reprod 24(9): 2173-2182.

23. Gürhan N, Akyüz A, Atici D, Kisa S (2009) Association of depression and anxiety with oocyte and sperm numbers and pregnancy outcomes during in vitro fertilization treatment. Psychol Rep 104(3): 796-806.

24. Karlidere T, Bozkurt A, Ozmenler KN, Ozsahin A, Kucuk T, et al. (2008) The influence of emotional distress on the outcome of in-vitro fertilization (IVF) and/or intracytoplasmic sperm injection (ICSI) treatment among infertile Turkish women. Isr J Psychiatry Relat Sci 45(1): 55-64.

25. Boivin J, Griffiths E, Venetis C (2011) Emotional distress in infertile women and failure of assisted reproductive technologies: metaanalysis of prospective psychosocial studies. BMJ 342: d223.

26. Anderheim L, Holter H, Bergh C, Möller A (2005) Does psychological stress affect the outcome of in vitro fertilization? Human Reproduction 20(10): 2969-2975.

27. Olivius C, Friden B, Borg G, Bergh C (2004) Why do couples discontinue in vitro fertilization treatment? A cohort study. Fertil Steril 81(2): 258261.

28. Rajkhowa M, McConnell A, Thomas GE (2006) Reasons for discontinuation of IVF treatment: a questionnaire study. Hum Reprod 21(2): 358-363.

29. Sengupta P (2012) Challenge of infertility: How protective the yoga therapy is? Anc Sci Life 32(1): 61-62.

30. Khalsa HK (2003) Yoga: an adjunct to infertility treatment. Fertil Steril 80 (Suppl 4): 46-51. 
31. Valoriani V, Lotti F, Vanni C, Noci MC, Fontanarosa N, et al. (2014) Hatha-yoga as a psychological adjuvant for women undergoing IVF: a pilot study. Eur J Obstet Gynecol Reprod Biol 176: 158-162.

32. Li J, Long L, Liu Y, He W, Li M (2016) Effects of a mindfulness-based intervention on fertility quality of life and pregnancy rates among women subjected to first in vitro fertilization treatment. Behav Res Ther 77: 96-104.

33. Psaros C, Kagan L, Shifren JL, Willett J, Jacquart J, et al. (2015) Mindbody group treatment for women coping with infertility: a pilot study J Psychosom Obstet Gynaecol 36(2): 75-83.
34. Jasani S, Heller B, Jasulaitis S, Davidson M, Hirshfeld Cytron J (2016) Impact of a Structured Yoga Program on Anxiety in Infertility Patients: A Feasibility Study. Journal of Fertilization: In vitro-IVF-Worldwide, Reproductive Medicine, Genetics \& Stem Cell Biology.

35. Oron G, Allnutt E, Lackman T, Sokal Arnon T, Holzer H, et al. (2015) A prospective study using Hatha Yoga for stress reduction among women waiting for IVF treatment. Reprod Biomed Online 30(5): 542-548.

36. Anon (2012) Pregnancy after assisted reproductive technology. Cambridge: Cambridge University Press, USA.

\section{Your next submission with Juniper Publishers} will reach you the below assets

- Quality Editorial service

- Swift Peer Review

- Reprints availability

- E-prints Service

- Manuscript Podcast for convenient understanding

- Global attainment for your research

- Manuscript accessibility in different formats

( Pdf, E-pub, Full Text, Audio)

- Unceasing customer service

Track the below URL for one-step submission https://juniperpublishers.com/online-submission.php 